Supporting Information

\title{
Tailoring Carbosilane Side Chains towards Intrinsically Stretchable Semiconducting Polymers
}

Yun-Chi Chiang, ${ }^{\mathrm{a},+}$ Hung-Chin Wu, ${ }^{\mathrm{a},+}$ Han-Fang Wen, ${ }^{\mathrm{b},+}$ Chih-Chien Hung, ${ }^{\mathrm{c},+}$ Chian-Wen Hong, ${ }^{a}$ Chi-Ching Kuo, ${ }^{\mathrm{b}}$ Tomoya Higashiharad,*, Wen-Chang Chen ${ }^{\mathrm{a}, \mathrm{e}, *}$

a Department of Chemical Engineering, National Taiwan University, Taipei 10617, Taiwan

${ }^{\mathrm{b}}$ Department of Molecular Science and Engineering, National Taipei University of Technology, Taipei 10608, Taiwan

${ }^{\mathrm{c}}$ Institute of Polymer Science and Engineering, National Taiwan University, Taipei 10617, Taiwan

d Department of Organic Device Engineering, Graduate School of Science and Engineering, Yamagata University, 4-3-16, Jonan, Yonezawa, Yamagata 992-8510, Japan

e Advanced Research Center for Green Materials Science and Technology, National Taiwan University, Taipei 10617, Taiwan

Cooresponding E-mail: chenwc@ntu.edu.tw (W.-C. C.); thigashihara@yz.yamagata-u.ac.jp (T. H.)

+ Y.-C. Chiang, H.-C. Wu, H.-F. Wen, and C.-C. Hung contributed equally to this work 


\section{Materials}

Dichloromethylsilane, hexylmagnesium bromide (2.0 M in diethyl ether), octylmagnesium bromide (2.0 M in diethyl ether), 7-bromo-1-heptene, 9-bromo-1-nonene, 10-bromo-1-decene, 2-(tributylstannyl)thiophene, trimethyltin chloride, 6-bromoisatin, 6-bromooxindole, Karstedt's catalyst (platinumdivinyltetramethyl-siloxane complex in xylene, $3 \mathrm{wt} \%)$, tri( $o$-tolyl)phosphine, tris(dibenzylideneacetone)dipalladium(0), common organic solvents (tetrahydrofuran, toluene, acetic acid, and dimethylformamide), and anhydrous solvents (i.e. chloroform and chlorobenzene) were purchased from Aldrich (St. Louis, MO, USA) and used as received.

$$
\text { 6,6'-Dibromoisoindigo (IID) })^{\mathrm{S} 1} \text { and 5,5'-bis(trimethylstannyl)-2,2'-bithiophene (2T) }{ }^{\mathrm{S} 2} \text { were }
$$
synthesized according to the reported procedures. The synthetic steps of PII2T-C7, PII2T-C9, and PII2T-C10 are shown in Scheme S1 and their ${ }^{1} \mathrm{H}-\mathrm{NMR}$ spectra are summarized, as depicted in Figures S1 S12. Note that PII2T-C6 and PII2T-C8 are prepared based on our previous study. ${ }^{\mathrm{S} 3}$

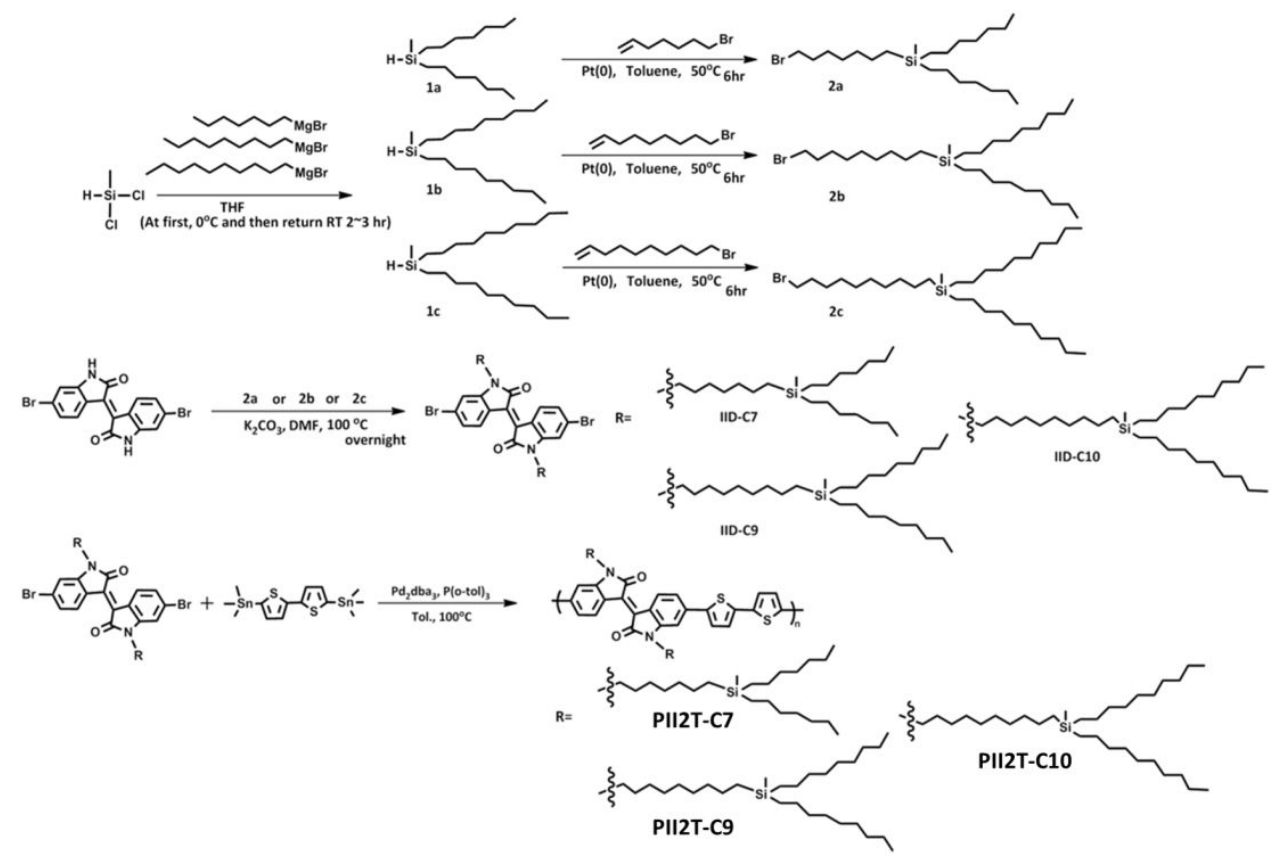


Scheme S1. Synthetic routes of PII2T-C7, PII2T-C9 and PII2T-C10.

\section{Synthesis of diheptyl(methyl)silane (1a)}

The dichloromethylsilane $(2.30 \mathrm{~g}, 20 \mathrm{mmol})$ and heptylmagnesium bromide solution $(8.14 \mathrm{~g}, 40$ mmol) mixed in $45 \mathrm{~mL}$ tetrahydrofuran were prepared in a two-neck flask at $0{ }^{\circ} \mathrm{C}$. The mixtures were slowly returned to room temperature and reacted for an additional $2 \mathrm{~h}$. Then the mixtures were quenched using methanol and the solvent (i.e. tetrahydrofuran and methanol) was evaporated under vacuum. Next, the mixtures were extracted with water and diethyl ether, and the organic layer extract was dried over $\mathrm{MgSO}_{4}$ to remove water, and the solvent was evaporated under vacuum. The crude products were purified by hexane to obtain $(4.71 \mathrm{~g}, 97 \%)$ as a colorless liquid. ${ }^{1} \mathrm{H}-\mathrm{NMR}$ (400 $\left.\mathrm{MHz}, \mathrm{CDCl}_{3}\right), \delta(\mathrm{ppm}): 3.75(\mathrm{~m}, 1 \mathrm{H}), 1.38-1.21(\mathrm{~m}, 20 \mathrm{H}), 0.94-0.83(\mathrm{~m}, 6 \mathrm{H}), 0.64-0.50(\mathrm{~d}, 4 \mathrm{H})$, 0.09-0.00 (m, 3H).

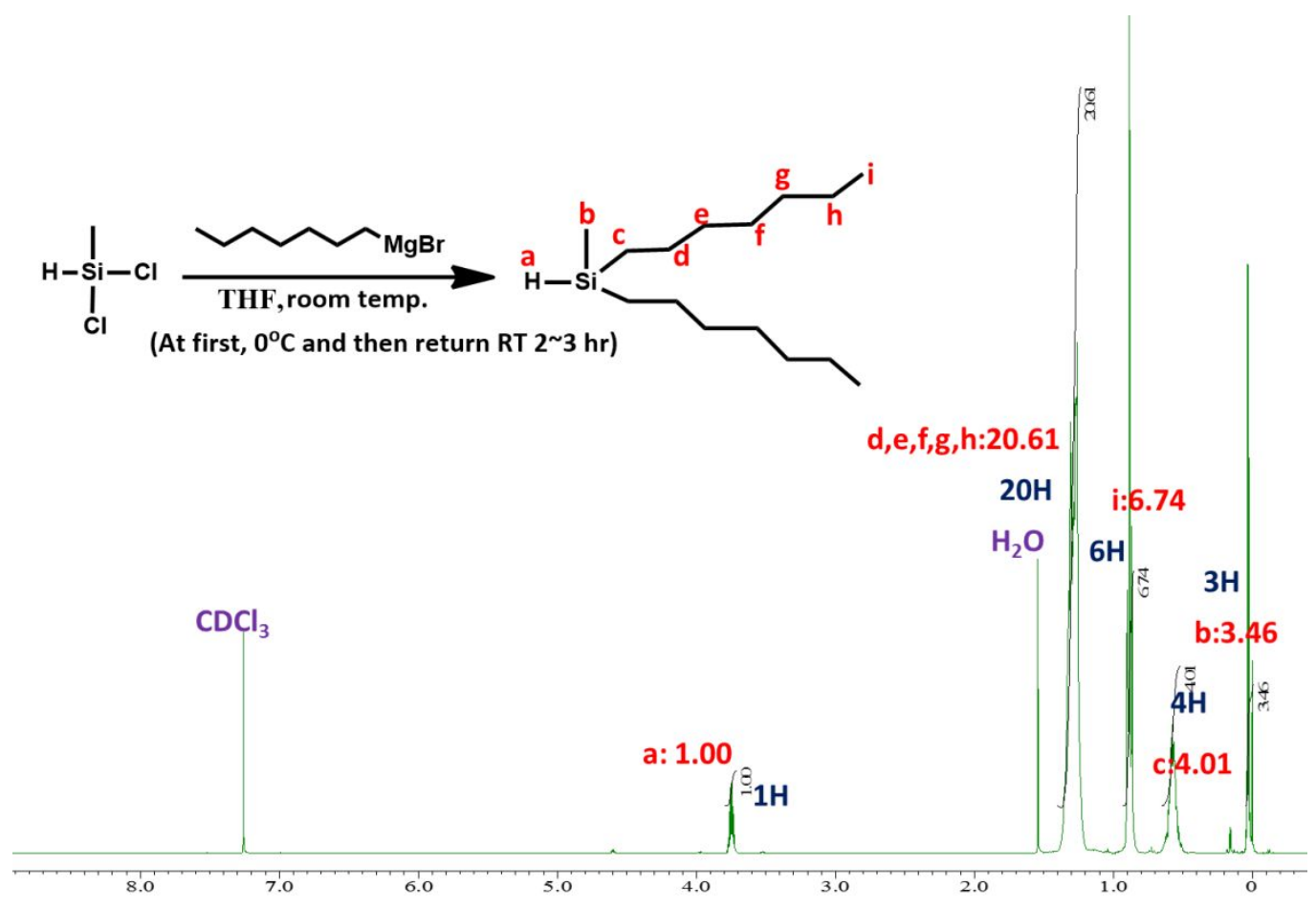

Figure S1. ${ }^{1} \mathrm{H}-\mathrm{NMR}$ spectrum of compound 1a. 


\section{Synthesis of methyldinonylsilane (1b)}

The dichloromethylsilane $(2.30 \mathrm{~g}, 20 \mathrm{mmol})$ and nonylmagnesium bromide solution $(9.25 \mathrm{~g}, 40$ mmol) mixed in $45 \mathrm{~mL}$ tetrahydrofuran were prepared in a two-neck flask at $0{ }^{\circ} \mathrm{C}$. The mixtures were slowly returned to room temperature and reacted for additional $2 \mathrm{~h}$. Then the mixtures were quenched using methanol and the solvent (i.e. tetrahydrofuran and methanol) was evaporated under vacuum. Next, the mixtures were extracted with water and diethyl ether, and the organic layer extract was dried over $\mathrm{MgSO}_{4}$ to remove water, and the solvent was evaporated under vacuum. The crude products were purified by hexane to obtain $(5.97 \mathrm{~g}, 92 \%)$ as a colorless liquid. ${ }^{1} \mathrm{H}-\mathrm{NMR}$ (400 $\left.\mathrm{MHz}, \mathrm{CDCl}_{3}\right), \delta(\mathrm{ppm}): 3.75(\mathrm{~m}, 1 \mathrm{H}), 1.38-1.21(\mathrm{~m}, 28 \mathrm{H}), 0.94-0.83(\mathrm{~m}, 6 \mathrm{H}), 0.64-0.50(\mathrm{~d}, 4 \mathrm{H})$, 0.09-0.00 (m, 3H).
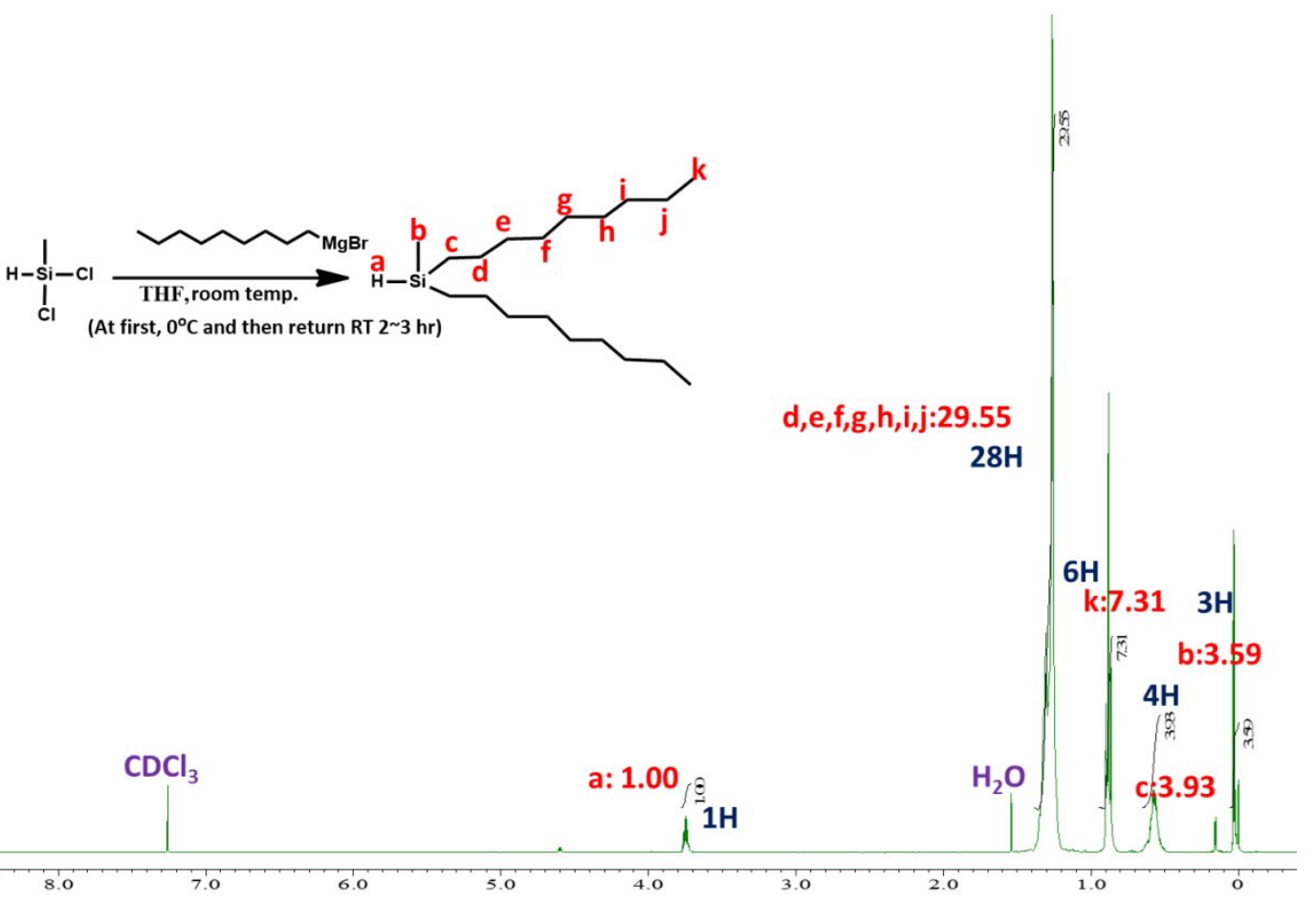

Figure S2. ${ }^{1} \mathrm{H}-\mathrm{NMR}$ spectrum of compound $1 \mathrm{~b}$. 


\section{Synthesis of didecyl(methyl)silane (1c)}

The dichloromethylsilane $(1.15 \mathrm{~g}, 10 \mathrm{mmol})$ and decylmagnesium bromide solution $(4.9 \mathrm{~g}, 40$ mmol) mixed in $23 \mathrm{~mL}$ tetrahydrofuran were prepared in a two-neck flask at $0{ }^{\circ} \mathrm{C}$. The mixtures were slowly returned to room temperature and reacted for additional $2 \mathrm{~h}$. Then the mixtures were quenched using methanol and the solvent (i.e. tetrahydrofuran and methanol) was evaporated under vacuum. Next, the mixtures were extracted with water and diethyl ether, and the organic layer extract was dried over $\mathrm{MgSO}_{4}$ to remove water, and the solvent was evaporated under vacuum. The crude products were purified by hexane to obtain $1 \mathrm{~b}(2.99 \mathrm{~g}, 92 \%)$ as a colorless liquid. ${ }^{1} \mathrm{H}-\mathrm{NMR}$ (400 MHz, CDCl3), $\delta(\mathrm{ppm}): 3.75(\mathrm{~m}, 1 \mathrm{H}), 1.38-1.21(\mathrm{~m}, 32 \mathrm{H}), 0.94-0.83(\mathrm{~m}, 6 \mathrm{H}), 0.64-0.50(\mathrm{~d}$, 4H), 0.09-0.00 (m, 3H).

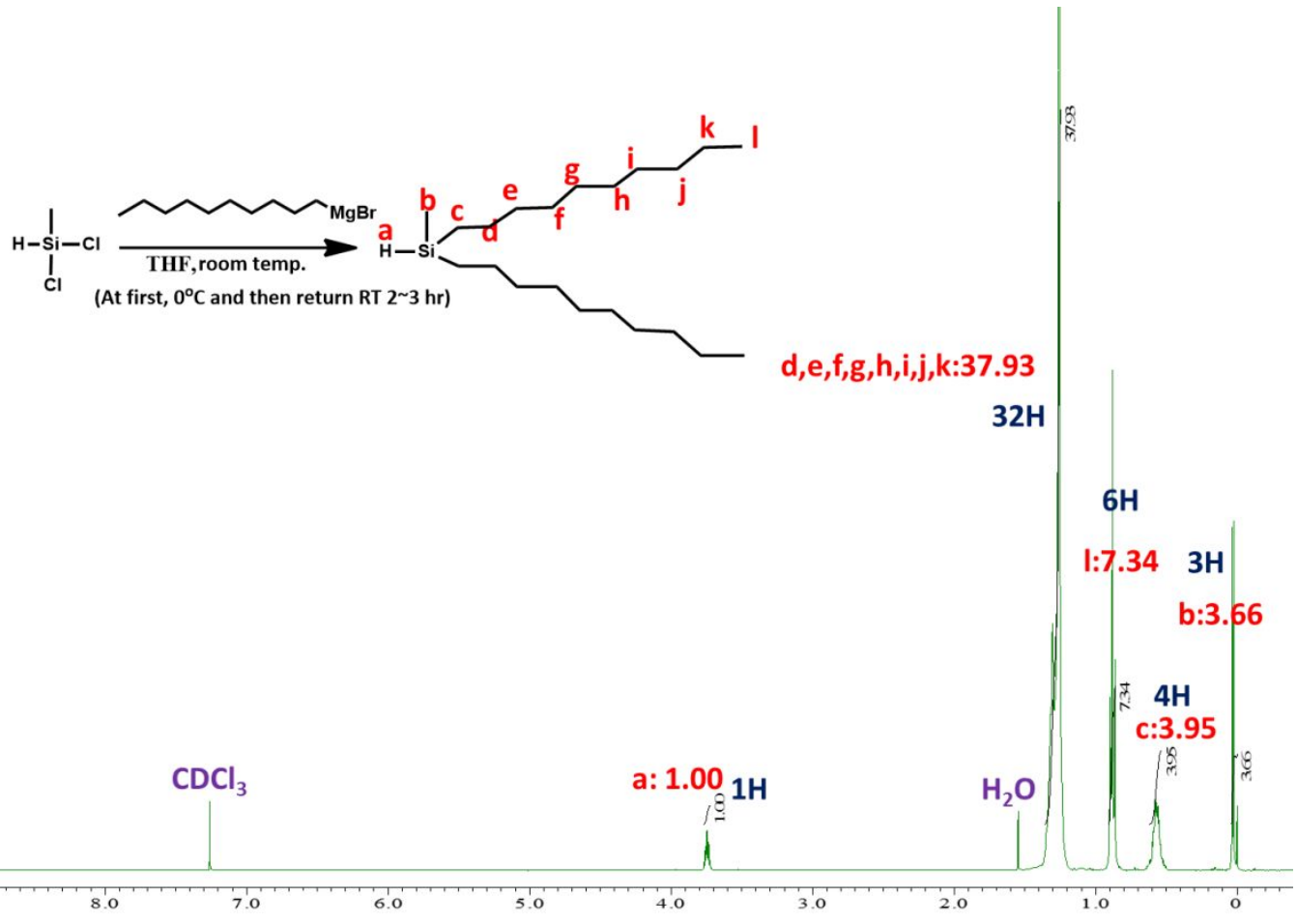

Figure S3. ${ }^{1} \mathrm{H}-\mathrm{NMR}$ spectrum of compound 1c. 


\section{Synthesis of (7-bromoheptyl) diheptyl(methyl)silane (2a)}

A mixture of 1a $(1.2 \mathrm{~g}, 5 \mathrm{mmol})$ and 7-bromo-1-heptene $(1.328 \mathrm{~g}, 7.5 \mathrm{mmol})$ was firstly prepared in a two-neck flask and purged nitrogen for $10 \mathrm{~min} .11 \mathrm{~mL}$ tetrahydrofuran and $8 \sim 9$ drops of Karstedt's catalyst were added subsequently, and the mixtures was heated up to $50{ }^{\circ} \mathrm{C}$ and reacted 6 hours. Afterward, the crude products were purified by chromatography using hexane as fluent to obtain $2 \mathrm{a}$ $(1.09 \mathrm{~g}, 52 \%)$ as a transparent oil. ${ }^{1} \mathrm{H}-\mathrm{NMR}\left(400 \mathrm{MHz}, \mathrm{CDCl}_{3}\right), \delta(\mathrm{ppm}): 3.40(\mathrm{~m}, 2 \mathrm{H}), 1.92-1.81$ (m, 2H), 1.49-1.18 (m, 28H), 0.92-0.83 (m, 6H), 0.52-0.40 (d, 6H), $-0.10(\mathrm{~d}, 3 \mathrm{H})$.

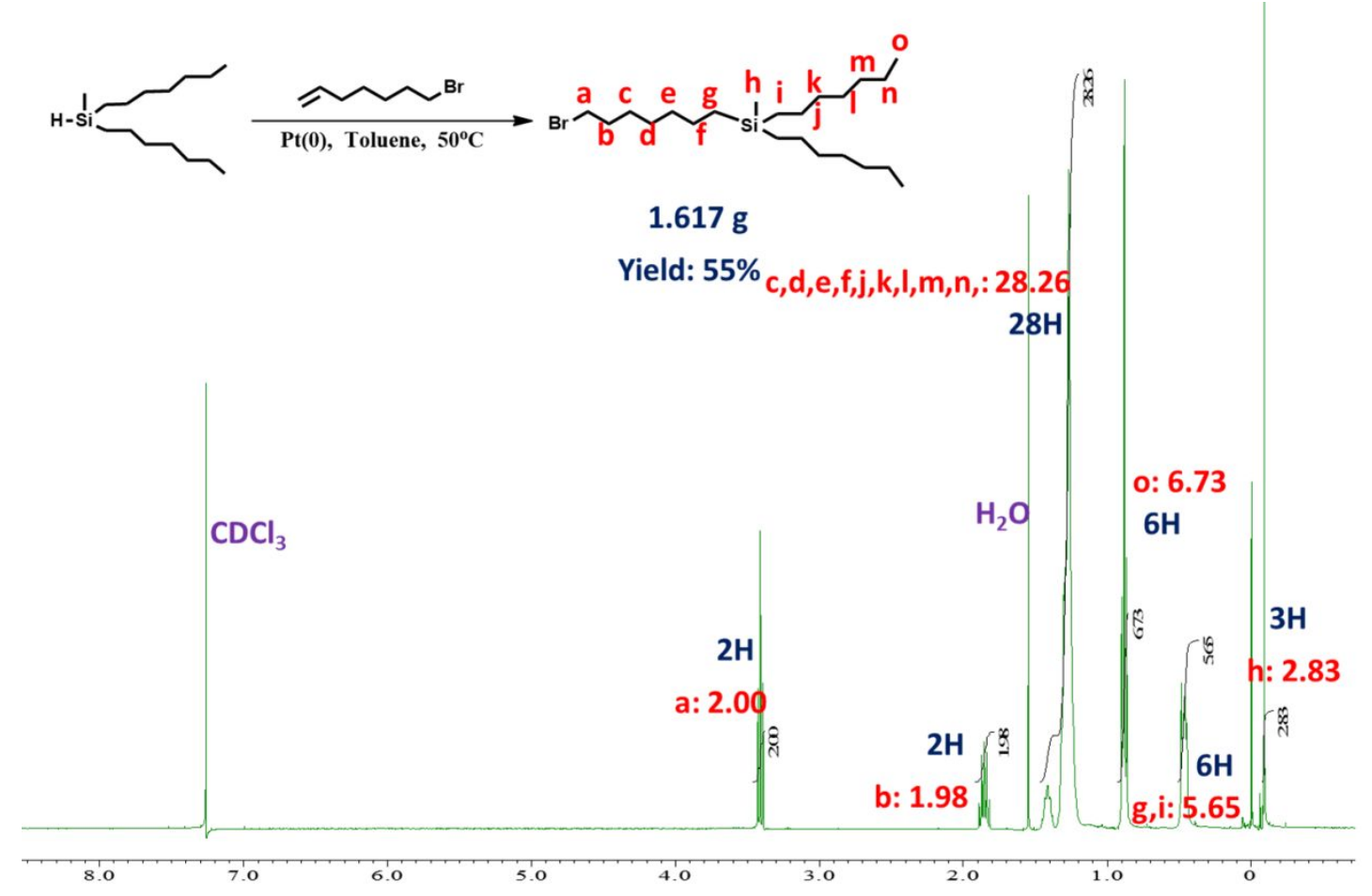

Figure S4. ${ }^{1} \mathrm{H}-\mathrm{NMR}$ spectrum of compound 2a. 


\section{Synthesis of (9-bromononyl)(methyl)dinonylsilane (2b)}

A mixture of $1 \mathrm{~b}(1.50 \mathrm{~g}, 5.02 \mathrm{mmol})$ and 9-bromo-1-nonene $(1.54 \mathrm{~g}, 7.53 \mathrm{mmol})$ was firstly prepared in a two-neck flask and purged nitrogen for $10 \mathrm{~min}$. $11 \mathrm{~mL}$ toluene and $8 \sim 9$ drops of Karstedt's catalyst were added subsequently, and the mixtures was heated up to $50{ }^{\circ} \mathrm{C}$ and reacted 6 hours. Afterward, the crude products were purified by chromatography using hexane as fluent to obtain $2 \mathrm{~b}(0.73 \mathrm{~g}, 30 \%)$ as a transparent oil. ${ }^{1} \mathrm{H}-\mathrm{NMR}\left(400 \mathrm{MHz}, \mathrm{CDCl}_{3}\right), \delta(\mathrm{ppm}): 3.40(\mathrm{~m}, 2 \mathrm{H})$, $1.92-1.81(\mathrm{~m}, 2 \mathrm{H}), 1.49-1.18(\mathrm{~m}, 38 \mathrm{H}), 0.92-0.83(\mathrm{~m}, 6 \mathrm{H}), 0.52-0.40(\mathrm{~d}, 6 \mathrm{H}),-0.10(\mathrm{~d}, 3 \mathrm{H})$.

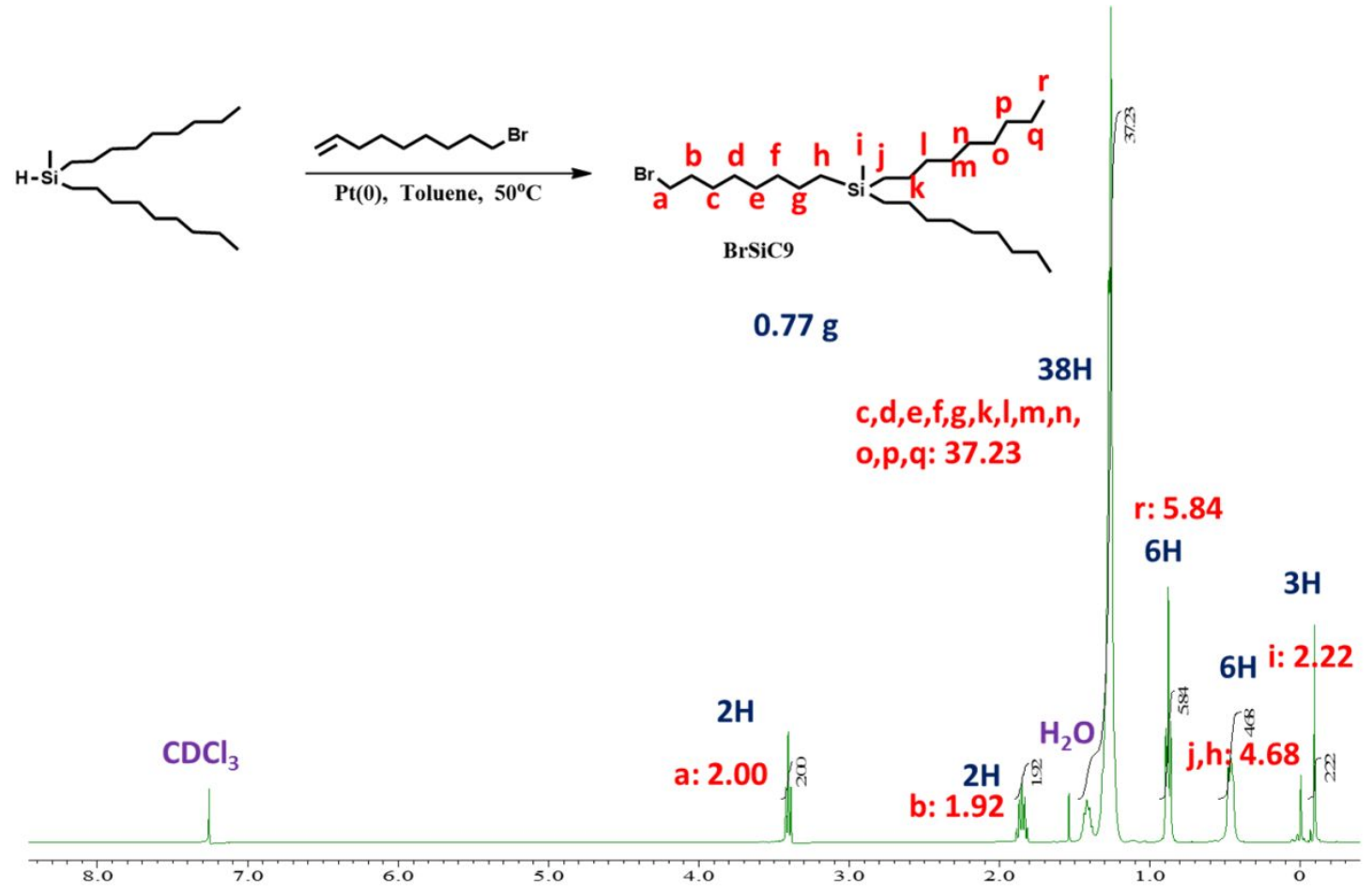

Figure S5. ${ }^{1} \mathrm{H}-\mathrm{NMR}$ spectrum of compound $2 \mathrm{~b}$. 


\section{Synthesis of (10-bromodecyl)didecyl(methyl)silane (2c)}

A mixture of $1 \mathrm{c}(1 \mathrm{~g}, 3.06 \mathrm{mmol})$ and 10-bromo-1-decene $(1.01 \mathrm{~g}, 4.59 \mathrm{mmol})$ was firstly prepared in a two-neck flask and purged nitrogen for $10 \mathrm{~min} .7 \mathrm{~mL}$ toluene and $4 \sim 5$ drops of Karstedt's catalyst were added subsequently, and the mixtures was heated up to $50{ }^{\circ} \mathrm{C}$ and reacted 6 hours. Afterward, the crude products were purified by chromatography using hexane as fluent to obtain 2c $(0.73 \mathrm{~g}, 40 \%)$ as a transparent oil. ${ }^{1} \mathrm{H}-\mathrm{NMR}\left(400 \mathrm{MHz}, \mathrm{CDCl}_{3}\right), \delta(\mathrm{ppm}): 3.40(\mathrm{~m}, 2 \mathrm{H}), 1.92-1.81$ (m, 2H), 1.49-1.18 (m, 46H), 0.92-0.83 (m, 6H), 0.54-0.40 (d, 6H), -0.10 (d, 3H).

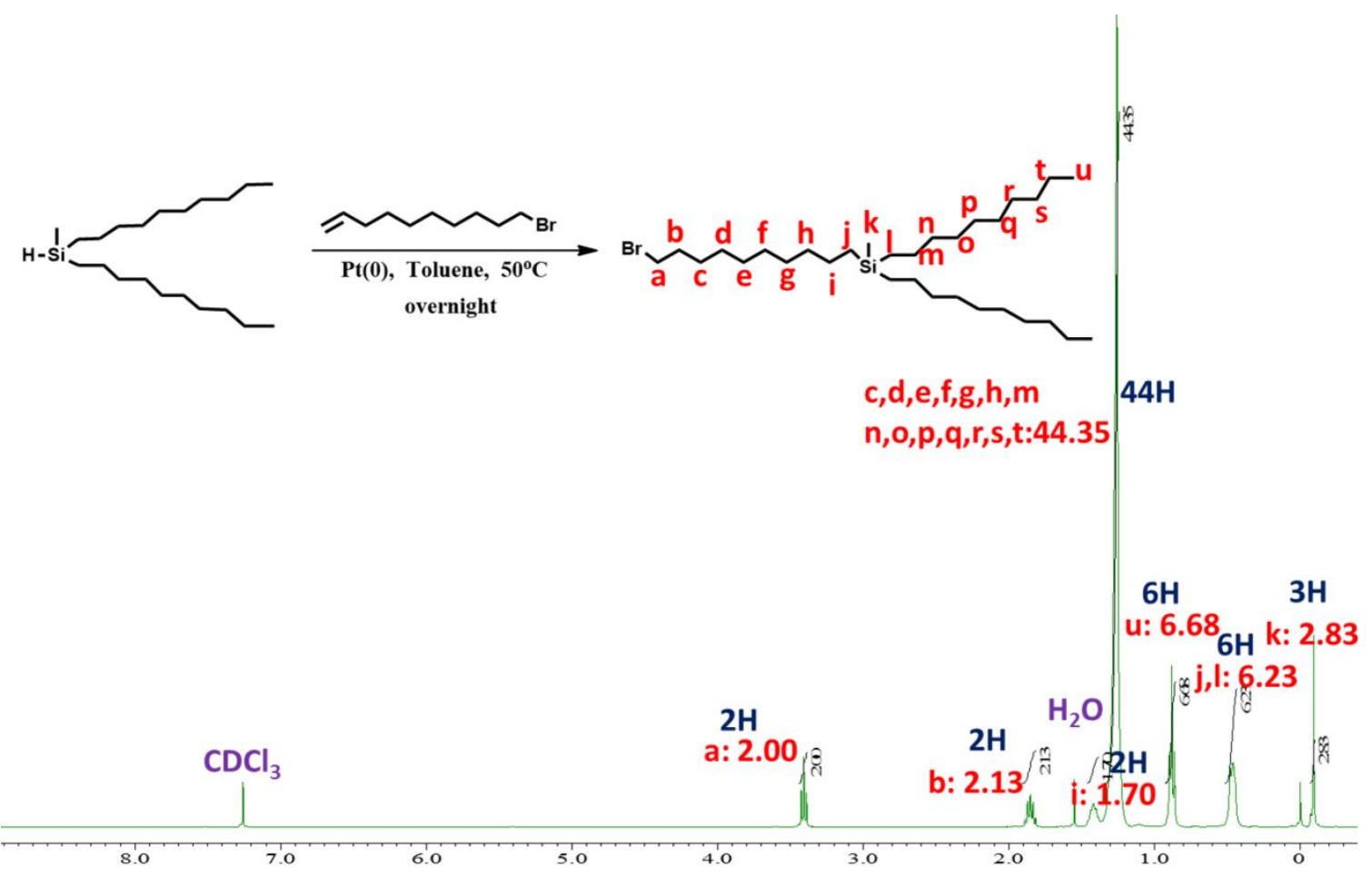

Figure S6. ${ }^{1} \mathrm{H}-\mathrm{NMR}$ spectrum of compound 2c. 


\section{Synthesis of IID-C7}

A suspension of 6,6'-dibromoisoindigo $(0.63 \mathrm{~g}, 1.48 \mathrm{mmol})$ and potassium carbonate $(1.03 \mathrm{~g}, 7.40$ $\mathrm{mmol})$ was prepared in $25 \mathrm{~mL}$ dimethylformaldehyde, then $2 \mathrm{a}(1.50 \mathrm{~g}, 3.50 \mathrm{mmol})$ was added under an nitrogen atmosphere. The mixture was heated up and stirred at $100{ }^{\circ} \mathrm{C}$ overnight. Afterwards, vacuum concentrator was used to remove the dimethylformaldehyde, then extracted using diethyl ether and water, and the organic layer extract was dried over $\mathrm{MgSO}_{4}$ to remove water. The solvent was evaporated used by vacuum concentrator. The crude products were further purified by chromatography using dichloromethane and hexane (v: $\mathrm{v}=1: 10)$ as fluent to obtain IID-C7 (1.09 g, $66 \%$ ) as a red oil. ${ }^{1} \mathrm{H}-\mathrm{NMR}\left(400 \mathrm{MHz}, \mathrm{CDCl}_{3}\right), \delta(\mathrm{ppm}): 9.08(\mathrm{~d}, 2 \mathrm{H}), 7.15,(\mathrm{dd}, 2 \mathrm{H}), 6.98(\mathrm{~d}, 2 \mathrm{H})$, $3.70(\mathrm{~d}, 4 \mathrm{H}), 1.78-1.60(\mathrm{~d}, 4 \mathrm{H}), 1.48-1.19(\mathrm{~m}, 56 \mathrm{H})$ 0.94-0.82 (m, 12H), 0.60-0.40 (m, 12H), -0.10 $(\mathrm{d}, 6 \mathrm{H})$.

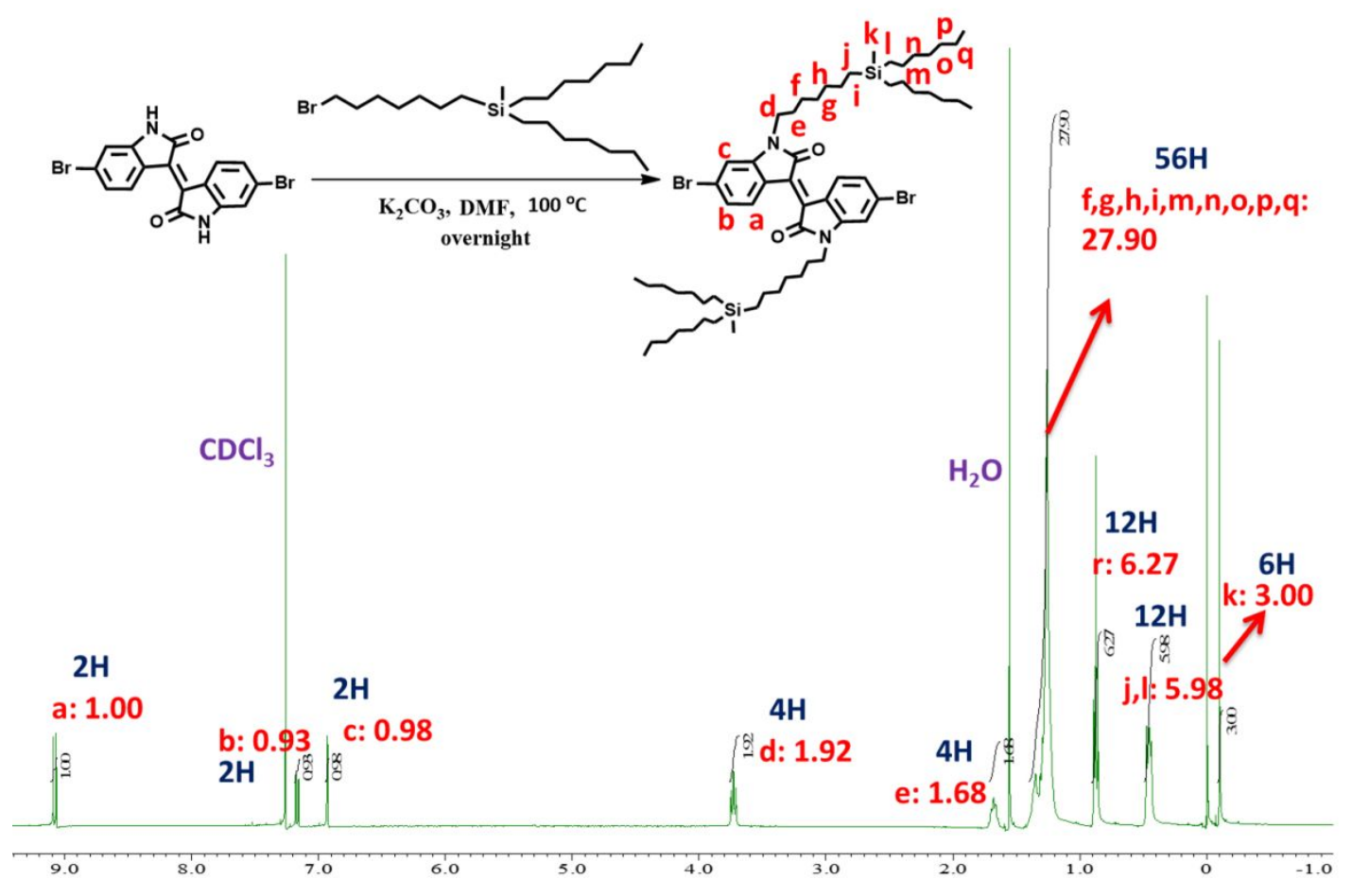


Figure S7. ${ }^{1} \mathrm{H}-\mathrm{NMR}$ spectrum of compound IID-C7.

\section{Synthesis of IID-C9}

A suspension of 6,6'-dibromoisoindigo $(0.28 \mathrm{~g}, 0.66 \mathrm{mmol})$ and potassium carbonate $(0.46 \mathrm{~g}, 3.30$ $\mathrm{mmol})$ was prepared in $11 \mathrm{~mL}$ dimethylformaldehyde, then $2 \mathrm{~b}(0.80 \mathrm{~g}, 1.59 \mathrm{mmol})$ was added under an nitrogen atmosphere. The mixture was heated up and stirred at $100{ }^{\circ} \mathrm{C}$ overnight. Afterwards, a vacuum concentrator was used to remove the dimethylformaldehyde, then extracted using diethyl ether and water, and the organic layer extract was dried over $\mathrm{MgSO}_{4}$ to remove water. The solvent was evaporated used by vacuum concentrator. The crude products were further purified by chromatography using dichloromethane and hexane (v:v = 1:10) as fluent to obtain IID-C9 (0.50 g, $60 \%$ ) as a red oil. ${ }^{1} \mathrm{H}-\mathrm{NMR}\left(400 \mathrm{MHz}, \mathrm{CDCl}_{3}\right), \delta(\mathrm{ppm}): 9.08(\mathrm{~d}, 2 \mathrm{H}), 7.15,(\mathrm{dd}, 2 \mathrm{H}), 6.98(\mathrm{~d}$, 2H), $3.70(\mathrm{~d}, 4 \mathrm{H}), 1.78-1.60(\mathrm{~d}, 4 \mathrm{H}), 1.48-1.19(\mathrm{~m}, 76 \mathrm{H})$ 0.94-0.82 (m, 12H), 0.60-0.40 (m, 12H), $-0.10(\mathrm{~d}, 6 \mathrm{H})$.

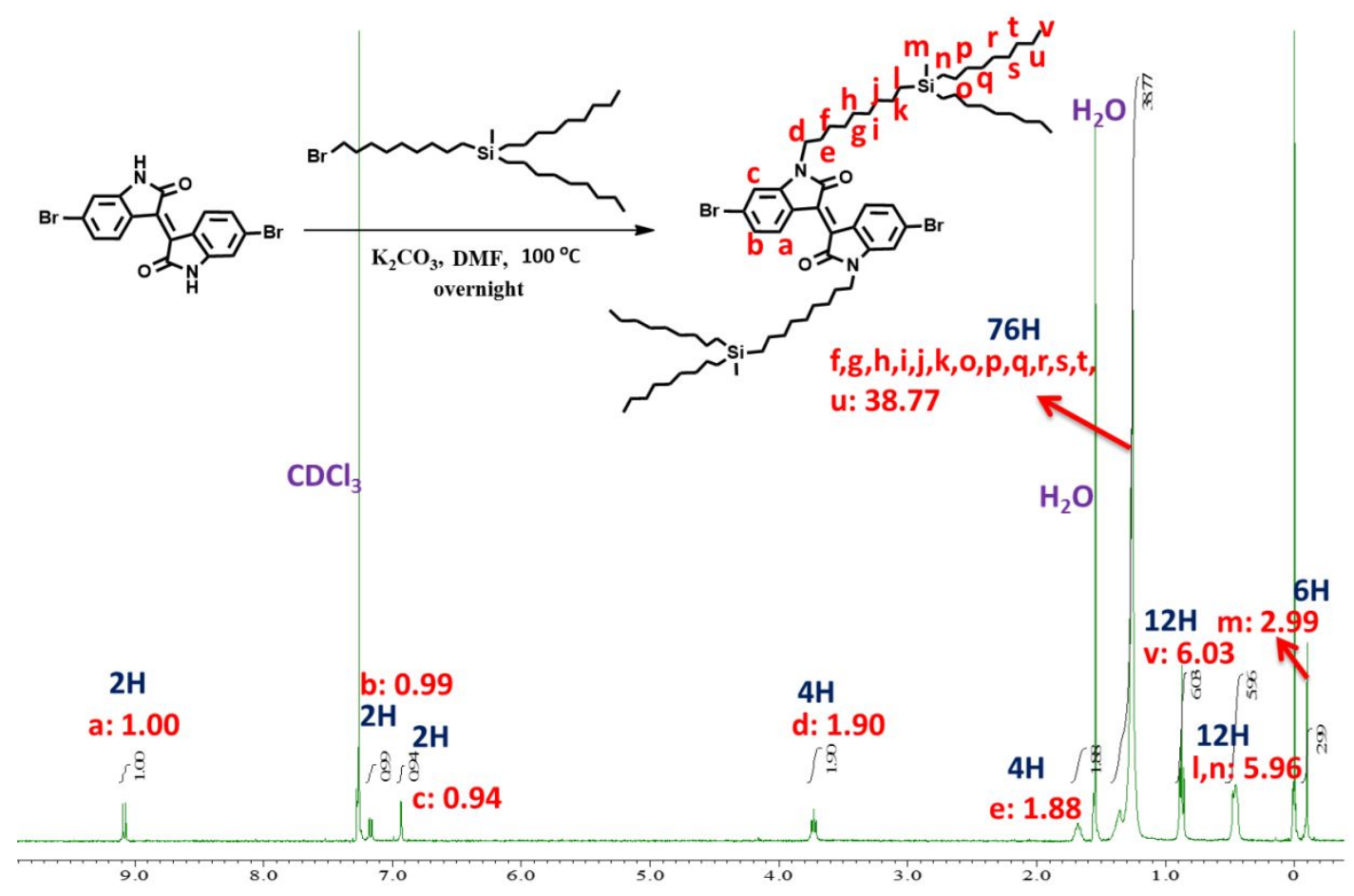


Figure S8. ${ }^{1} \mathrm{H}-\mathrm{NMR}$ spectrum of compound IID-C9.

\section{Synthesis of IID-C10}

A suspension of 6,6'-dibromoisoindigo $(0.48 \mathrm{~g}, 1.15 \mathrm{mmol})$ and potassium carbonate $(0.79 \mathrm{~g}, 5.73$ $\mathrm{mmol})$ was prepared in $19 \mathrm{~mL}$ dimethylformaldehyde, then $2 \mathrm{c}(1.50 \mathrm{~g}, 2.75 \mathrm{mmol})$ was added under an nitrogen atmosphere. The mixture was heated up and stirred at $100{ }^{\circ} \mathrm{C}$ overnight. Afterwards, avacuum concentrator was used to remove the dimethylformaldehyde, then extracted using diethyl ether and water, and the organic layer extract was dried over $\mathrm{MgSO}_{4}$ to remove water. The solvent was evaporated used by vacuum concentrator. The crude products were further purified by chromatography using dichloromethane and hexane (v:v = 1:10) as fluent to obtain IID-C10 (1.54 g, $60 \%)$ as a red oil. ${ }^{1} \mathrm{H}-\mathrm{NMR}\left(400 \mathrm{MHz}, \mathrm{CDCl}_{3}\right), \delta(\mathrm{ppm}): 9.08(\mathrm{~d}, 2 \mathrm{H}), 7.15,(\mathrm{dd}, 2 \mathrm{H}), 6.98(\mathrm{~d}, 2 \mathrm{H})$, $3.70(\mathrm{~d}, 4 \mathrm{H}), 1.72-1.62(\mathrm{~d}, 4 \mathrm{H}), 1.42-1.19(\mathrm{~m}, 96 \mathrm{H})$ 0.94-0.82 (m, 12H), 0.54-0.40 (m, 12H), -0.10 $(\mathrm{d}, 6 \mathrm{H})$.

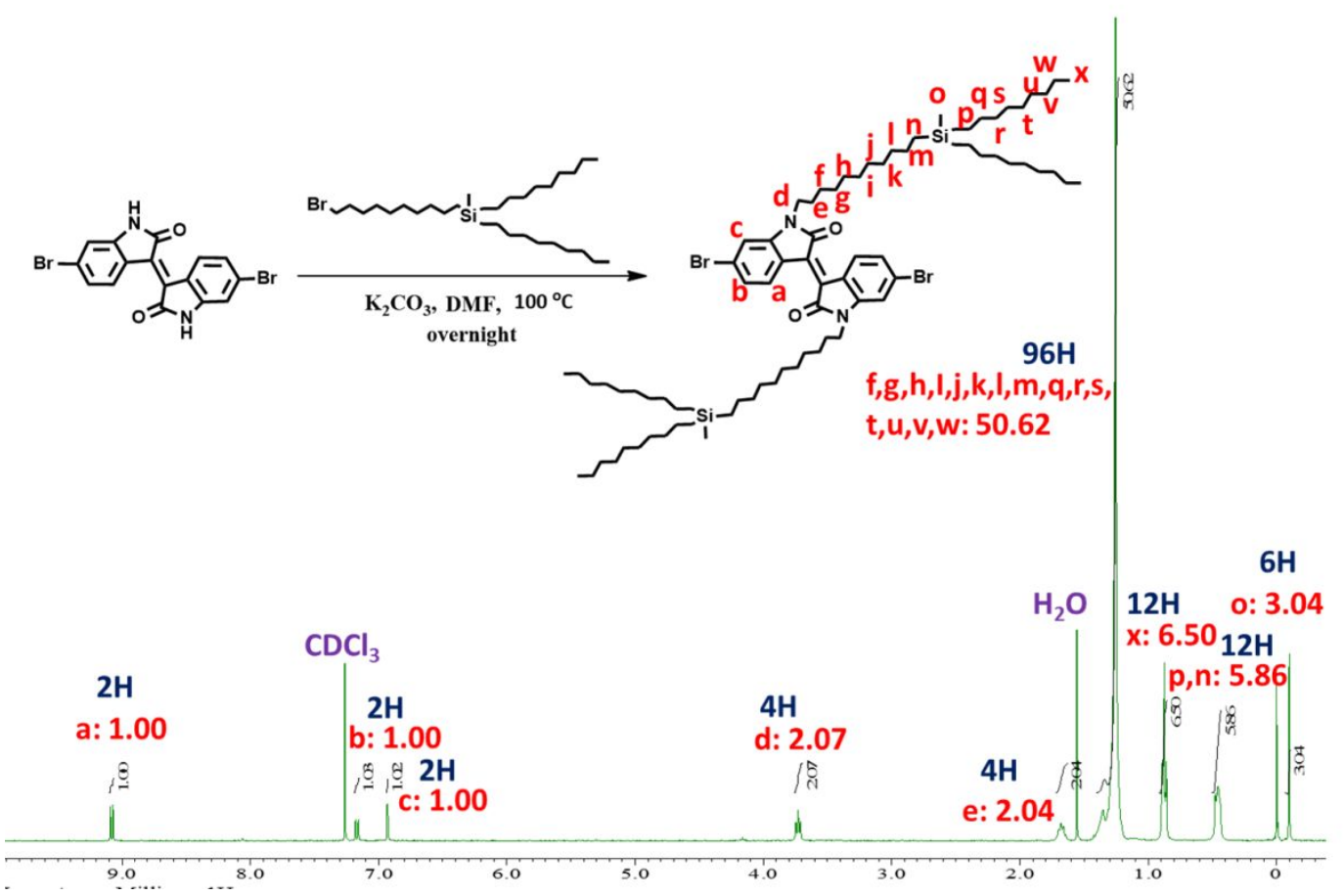


Figure S9. ${ }^{1} \mathrm{H}-\mathrm{NMR}$ spectrum of compound IID-C10.

\section{General Procedures for Polymerization}

The studied polymers are prepared by the following synthetic method: ditin monomer (i.e. 2T), dibromo isoindigos (i.e. IID-C7, IID-C9 or IID-C10), tri(o-tolyl)phosphine (30 mg), and tris(dibenzylideneacetone)dipalladium(0) $(15 \mathrm{mg})$ were dissolved by $5 \mathrm{~mL}$ chlorobenzene in a microwave vessel under nitrogen atmosphere. The vessel was then sealed and the monomers were polymerized via Stille coupling reaction at $180{ }^{\circ} \mathrm{C}$ for $60 \mathrm{~min}$ under microwave heating. Afterwards, the reaction was end-capped using 2-(tributylstannyl)thiophene and 2-bromothiophene (both 1.1 equiv. with respect to ditin monomer and under microwave heating at $185{ }^{\circ} \mathrm{C}$ for $10 \mathrm{~min}$ on the end-capping). Finally, the crude mixture was cooled and poured into methanol to form a crude polymer product. The crude polymer was purified using Soxhlet apparatus with methanol, acetone, and hexane to remove oligomers and catalyst residues. The final product was obtained after drying in a vacuum oven at $40{ }^{\circ} \mathrm{C}$.

\section{Synthesis of PII2T-C7}

IID-C7 (0.43 g, $0.39 \mathrm{mmol}), 2 \mathrm{~T}(0.19 \mathrm{~g}, 0.39 \mathrm{mmol})$ and $5 \mathrm{~mL}$ of chlorobenzene were used to afford a dark blue solid (yield: $312 \mathrm{mg}, 70 \%) .{ }^{1} \mathrm{H}-\mathrm{NMR}(400 \mathrm{MHz}$, Tetrachloroethane- $d 2), \delta(\mathrm{ppm})$ : 9.20-8.20 (br, Ar-H), 7.50-6.50 (br, Ar-H), 3.85-3.60 (br, $\left.\mathrm{Ar}-\mathrm{CH}_{2}\right), 1.95-0.98$ (br, $-\mathrm{CH}_{2}$ ), 0.98-0.70 (br, $\left.-\mathrm{CH}_{3}\right), 0.55-0.40\left(\mathrm{br},-\mathrm{CH}_{2}\right),-0.12\left(\mathrm{br},-\mathrm{CH}_{3}\right)$. Anal. Calcd for $\left[\mathrm{C}_{68} \mathrm{H}_{104} \mathrm{~N}_{2} \mathrm{O}_{2} \mathrm{~S}_{2} \mathrm{Si}_{2}\right]$ : C, 74.17; H, 9.45; N, 2.54; S, 5.82. Found: C, 73.11; H, 10.13; N, 2.42; S, 5.91. Number-average 
molecular weight and polydispersity index estimated from size exclusion chromatography (SEC) are $118 \mathrm{kDa}$ and 3.0, respectively.

\section{Synthesis of PII2T-C9}

IID-C9 (0.38 g, $0.3 \mathrm{mmol}), 2 \mathrm{~T}(0.15 \mathrm{~g}, 0.3 \mathrm{mmol})$ and $5 \mathrm{~mL}$ of chlorobenzene were used to afford a dark blue solid (yield: $235 \mathrm{mg}, 65 \%$ ). ${ }^{1} \mathrm{H}-\mathrm{NMR}$ (400 MHz, Tetrachloroethane- $\left.d_{2}\right), \delta(\mathrm{ppm})$ : 9.20-8.20 (br, Ar-H), 7.50-6.50 (br, Ar-H), 3.85-3.60 (br, $\left.\mathrm{Ar}-\mathrm{CH}_{2}\right), 1.95-0.98$ (br, $-\mathrm{CH}_{2}$ ), 0.98-0.70 (br, $\left.-\mathrm{CH}_{3}\right), 0.55-0.40\left(\mathrm{br},-\mathrm{CH}_{2}\right),-0.12$ (br, $\left.-\mathrm{CH}_{3}\right)$. Anal. Calcd for $\left[\mathrm{C}_{80} \mathrm{H}_{128} \mathrm{~N}_{2} \mathrm{O}_{2} \mathrm{~S}_{2} \mathrm{Si}_{2}\right]$ : C, 75.69; H, 10.09; N, 2.20; S, 5.04. Found: C, 74.29; H, 10.70; N, 1.98; S, 5.11. Number-average molecular weight and polydispersity index estimated from SEC are $70.4 \mathrm{kDa}$ and 1.86, respectively.

\section{Synthesis of PII2T-C10}

IID-C10 (0.43 g, $0.3 \mathrm{mmol}), 2 \mathrm{~T}(0.15 \mathrm{~g}, 0.3 \mathrm{mmol})$ and $5 \mathrm{~mL}$ of chlorobenzene were used to afford a dark blue solid (yield: $330 \mathrm{mg}, 78 \%$ ). ${ }^{1} \mathrm{H}-\mathrm{NMR}$ (400 MHz, Tetrachloroethane- $d_{2}$ ), $\delta(\mathrm{ppm})$ : 9.20-8.20 (br, $\mathrm{Ar}-\mathrm{H})$, 7.50-6.50 (br, $\mathrm{Ar}-\mathrm{H}), 3.85-3.60$ (br, $\left.\mathrm{Ar}-\mathrm{CH}_{2}\right), 1.95-0.98$ (br, $-\mathrm{CH}_{2}$ ), 0.98-0.70 (br, $\left.-\mathrm{CH}_{3}\right), 0.55-0.40$ (br, $\left.-\mathrm{CH}_{2}\right),-0.12$ (br, $-\mathrm{CH}_{3}$ ). Anal. Calcd for $\left[\mathrm{C}_{86} \mathrm{H}_{140} \mathrm{~N}_{2} \mathrm{O}_{2} \mathrm{~S}_{2} \mathrm{Si}_{2}\right]$ : C, 76.32; H, 10.35; N, 2.07; S, 4.73. Found: C, 76.20; H, 10.88; N, 1.93; S, 4.60. Number-average molecular weight and polydispersity index estimated from SEC are $137 \mathrm{kDa}$ and 1.94, respectively. 


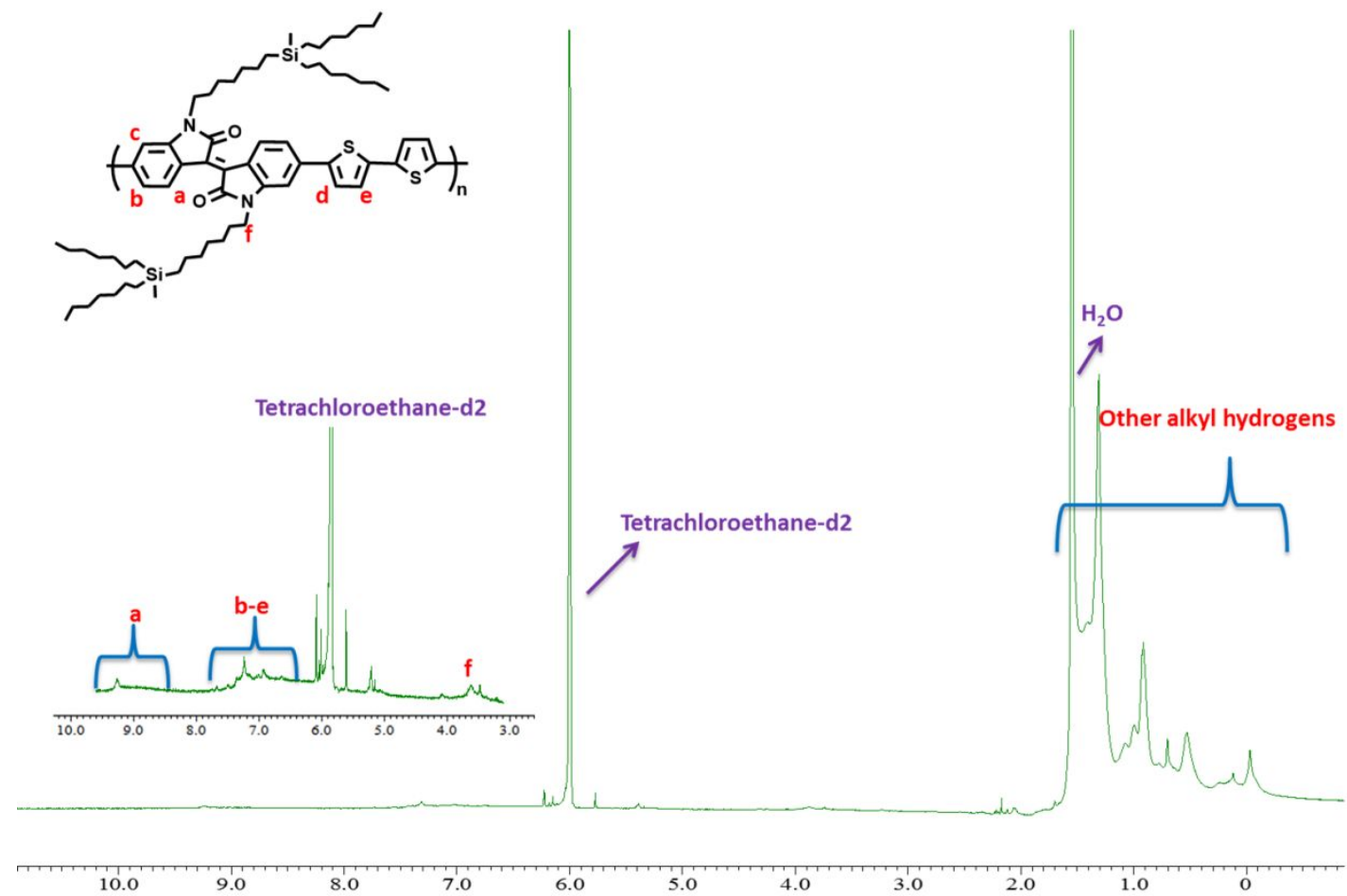

Figure S10. ${ }^{1} \mathrm{H}-\mathrm{NMR}$ spectrum of PII2T-C7.

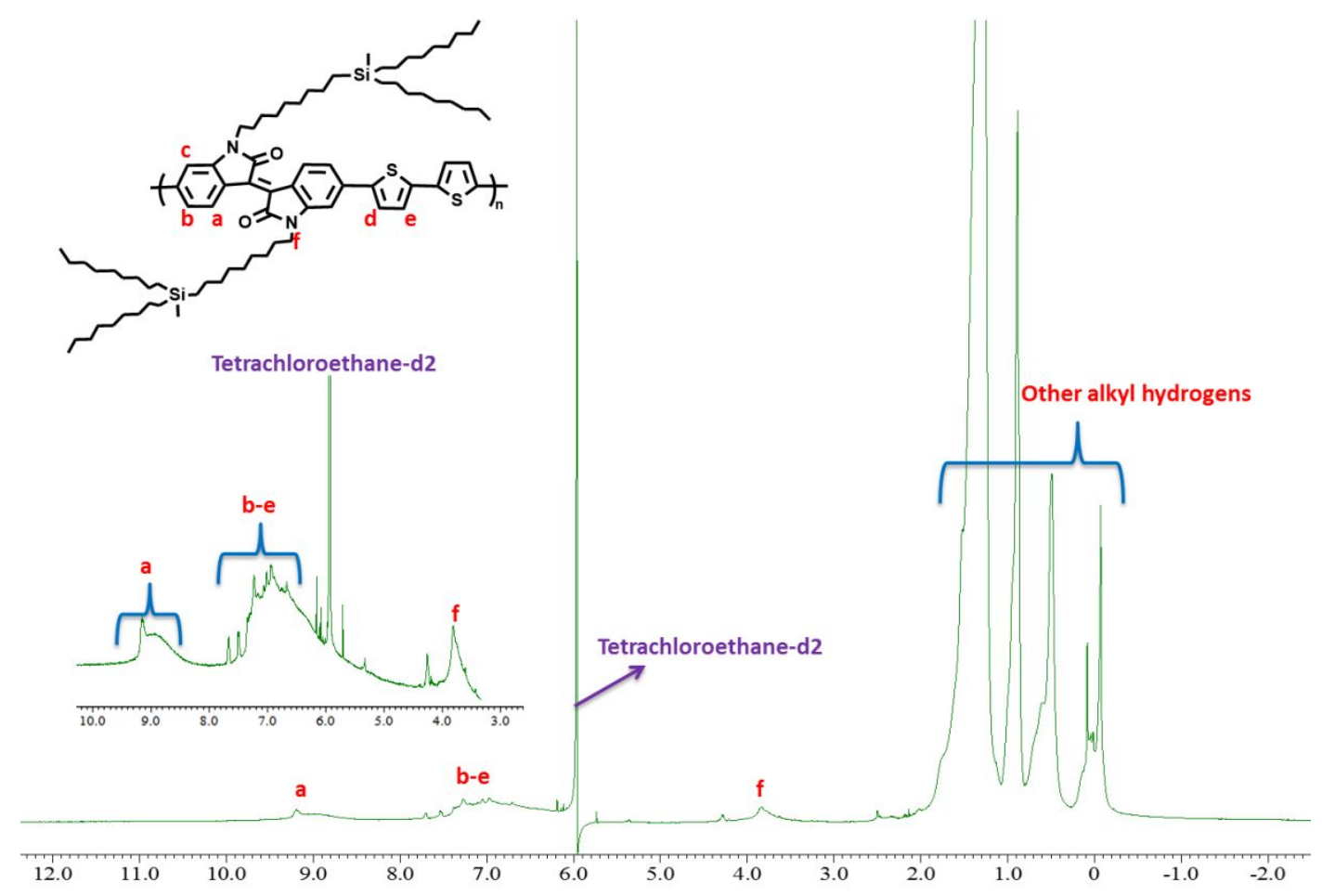

Figure S11. ${ }^{1} \mathrm{H}-\mathrm{NMR}$ spectrum of PII2T-C9. 


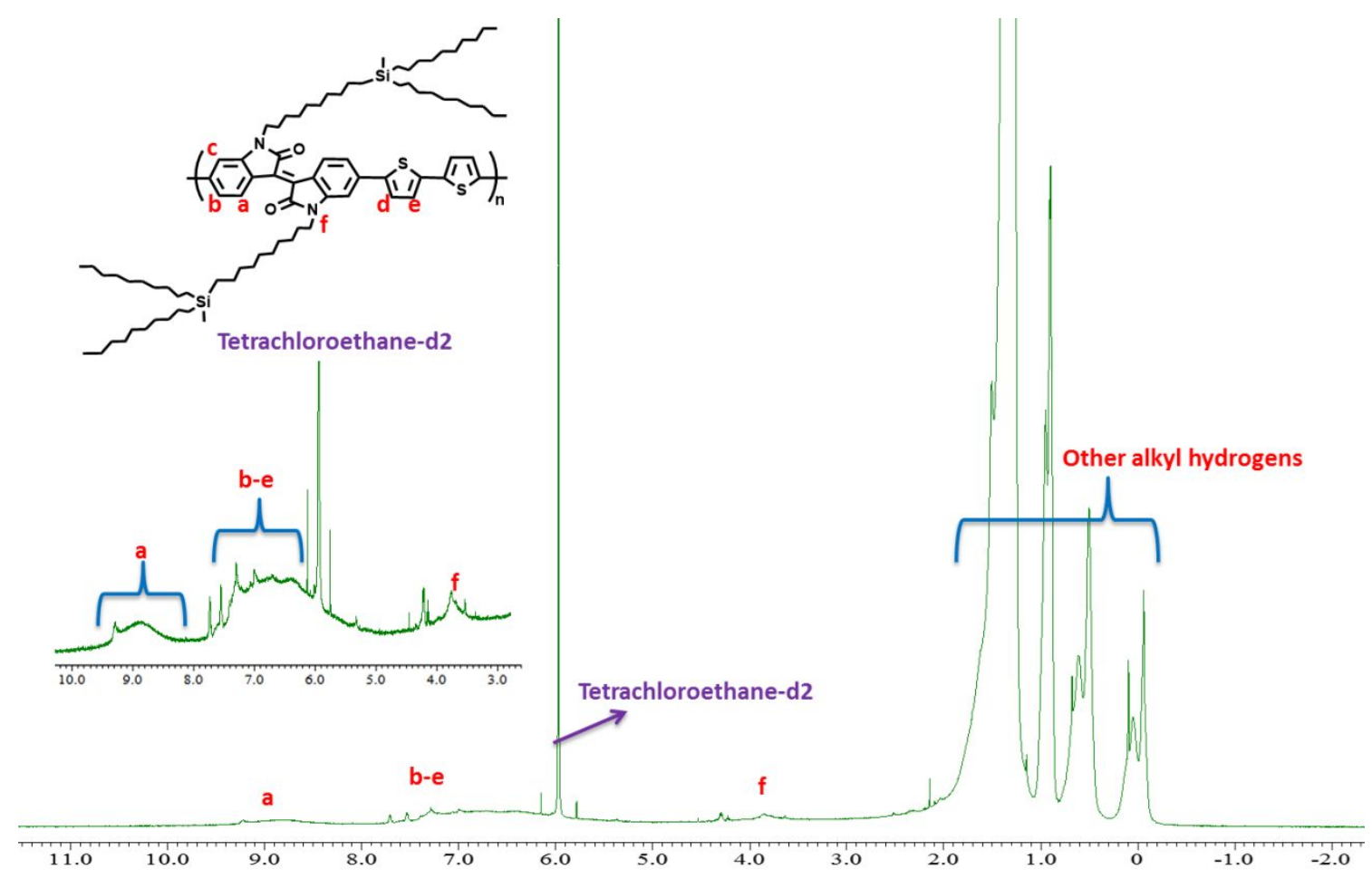

Figure S12. ${ }^{1} \mathrm{H}-\mathrm{NMR}$ spectrum of PII2T-C10.

\section{Characterizations}

Microwave polymerization was carried out using a Biotage microwave reactor in sealed vessels. ${ }^{1} \mathrm{H}-\mathrm{NMR}$ spectra was recorded using a Bruker Advance DRX-400 MHz spectrometer. Elemental analysis was performed by elementary Vario EL cube (for NCSH, Germany) with sulfanilic acid as standard. Size exclusion chromatographic (SEC) analysis was performed on a Lab Alliance RI2000 instrument (two column, MIXED-C and D from Polymer Laboratories) connected with one refractive index detector from Schambeck SFD Gmbh. All SEC analyses were performed on polymer/THF solution at a flow rate of $1 \mathrm{~mL} \mathrm{~min}^{-1}$ under $40{ }^{\circ} \mathrm{C}$, and then calibrated with polystyrene standards.

Thermogravimetric analysis (TGA) and differential scanning calorimetry (DSC) 
measurements were performed under a nitrogen atmosphere at a heating rate of $10{ }^{\circ} \mathrm{C} \mathrm{min}{ }^{-1}$ using the TA instruments (Q-50 and Q-100), respectively. UV-Vis absorption spectrum was collected using a Hitachi U-4100 spectrophotometer. Cyclic voltammetry (CV) was performed on a CHI 611D electrochemical analyzer using a three-electrode cell and the electrochemical properties of the polymer films were detected under $0.1 \mathrm{M}$ dry acetonitrile solution containing tetrabutylammonium perchlorate as the electrolyte. Grazing incidence X-ray diffraction (GIXD) measurements were carried out on beamline 17A1 and 13A1 in National Synchrotron Radiation Research Center (NSRRC) of Taiwan. An incident angle of $0.12^{\circ}$ was used. The morphology of the polymer film surface was obtained using a Nanoscope 3D Controller atomic force microscope (AFM, Digital Instruments (Santa Barbara, CA, USA)) operated in the tapping mode at room temperature. Note that the preparation of polymer thin film samples was the same as that of the device fabrications for the measurements of GIXD, UV, and AFM.

The mechanical property of thin films were measured using an AFM apparatus (Dimension Icon, Bruker) operated under PeakForceTM tapping mode. A standard silicon tips with a spring constant of 5 42 $\mathrm{N} \mathrm{m}^{-1}$ was used. The force set point for each measurement was adjusted to obtain a reliable fit in the unload region ( 2 to $10 \mathrm{~nm}$ ), and the tip oscillated at a frequency of $2 \mathrm{kHz}$ during measurement, which is far below from the cantilever resonant frequency $(300 \mathrm{kHz})$. The elastic modulus of samples, moreover, was fit by the Derjaguin-Muller-Toporov (DMT) model that applicable for systems with low adhesion and small tip radii. ${ }^{\mathrm{S}}$

All electrical characterizations, for both non-stretched and stretched PII2T films, were 
carried out by a Keithley 4200-SCS semiconductor parameter analyzer (Keithley Instruments Inc., Cleveland, $\mathrm{OH}, \mathrm{USA}$ ) in a $\mathrm{N}_{2}$-filled enviroment.

a)

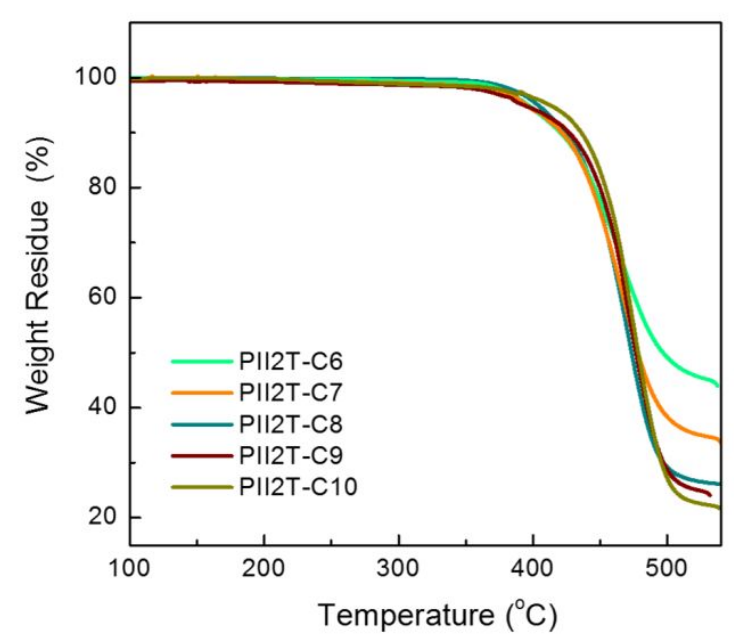

b)

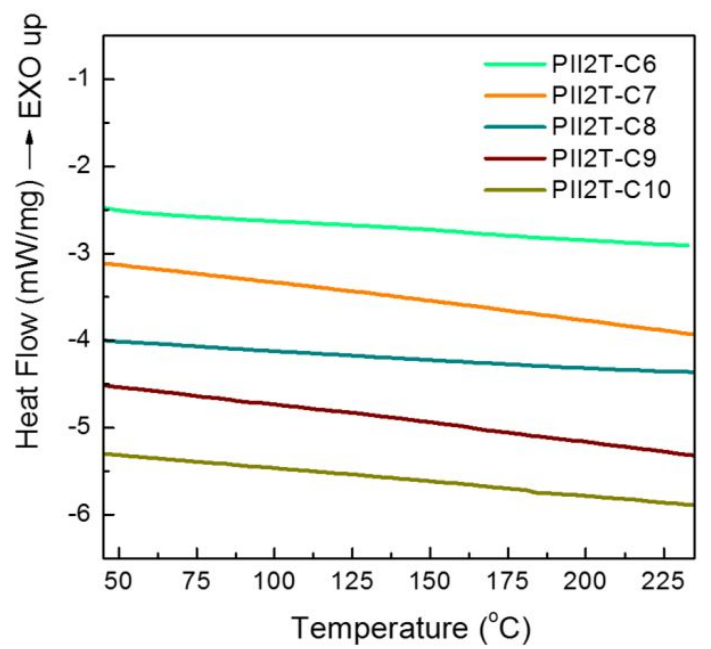

Figure S13. Thermal characteristics of the PII2T-based polymers: (a) TGA curves and (b) DSC traces.

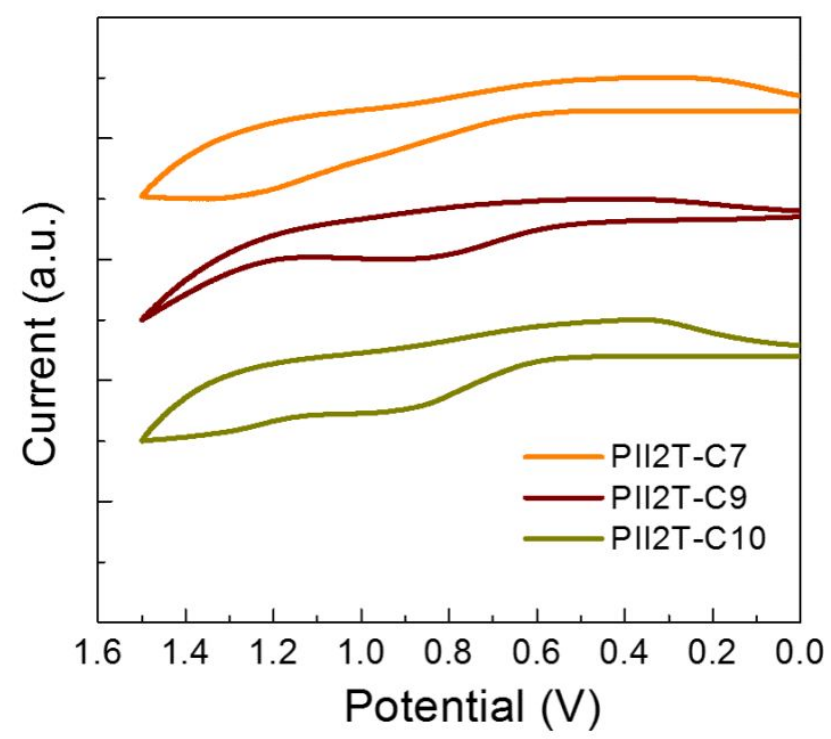

Figure S14. CV curves of the PII2T-C7, PII2T-C9 and PII2T-C10. 

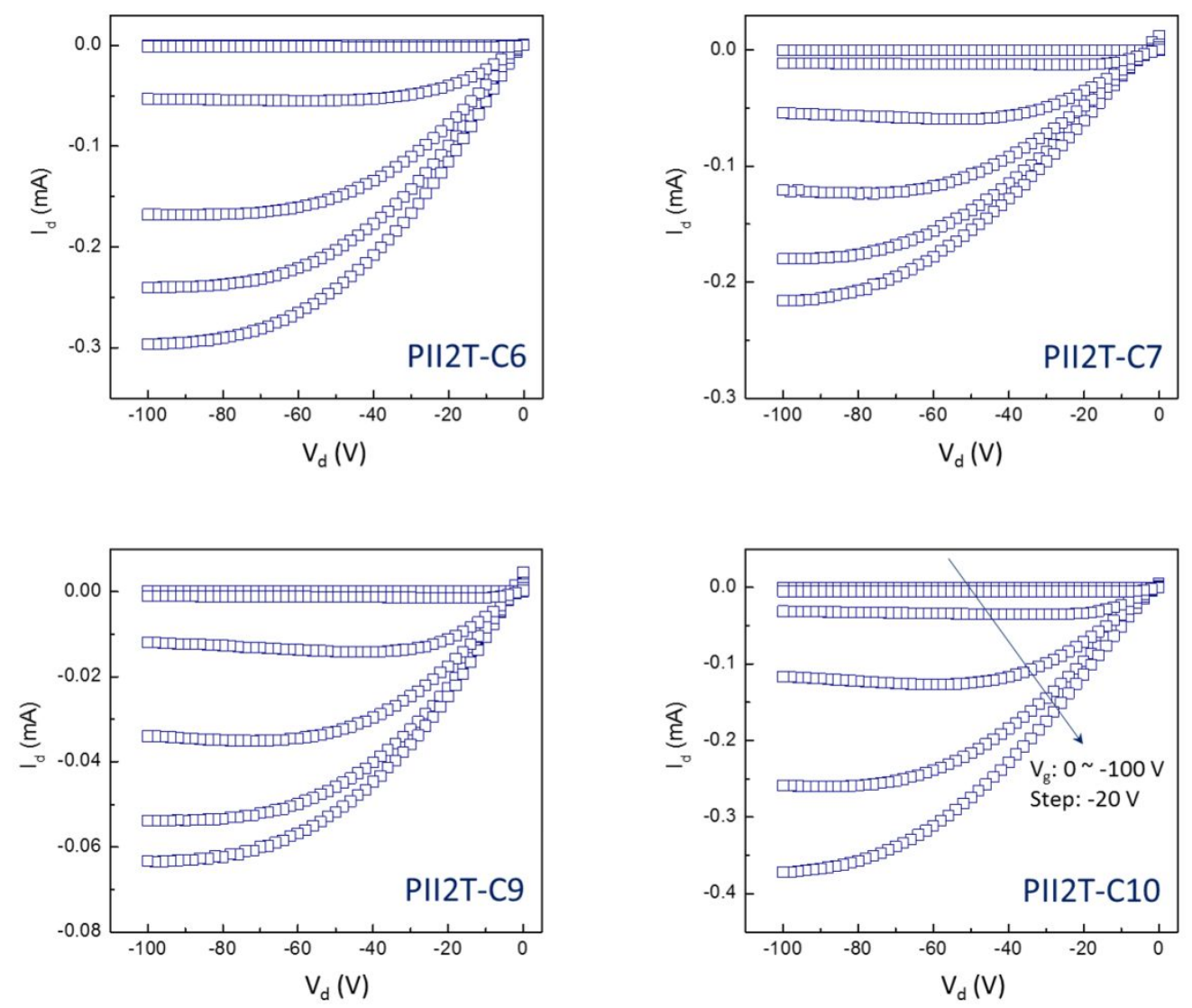

Figure S15. Output characteristics of FETs based on the studied polymer thin films. The gate voltage was scanned from 0 to $-100 \mathrm{~V}$, with a step of $-20 \mathrm{~V}$. 
S D
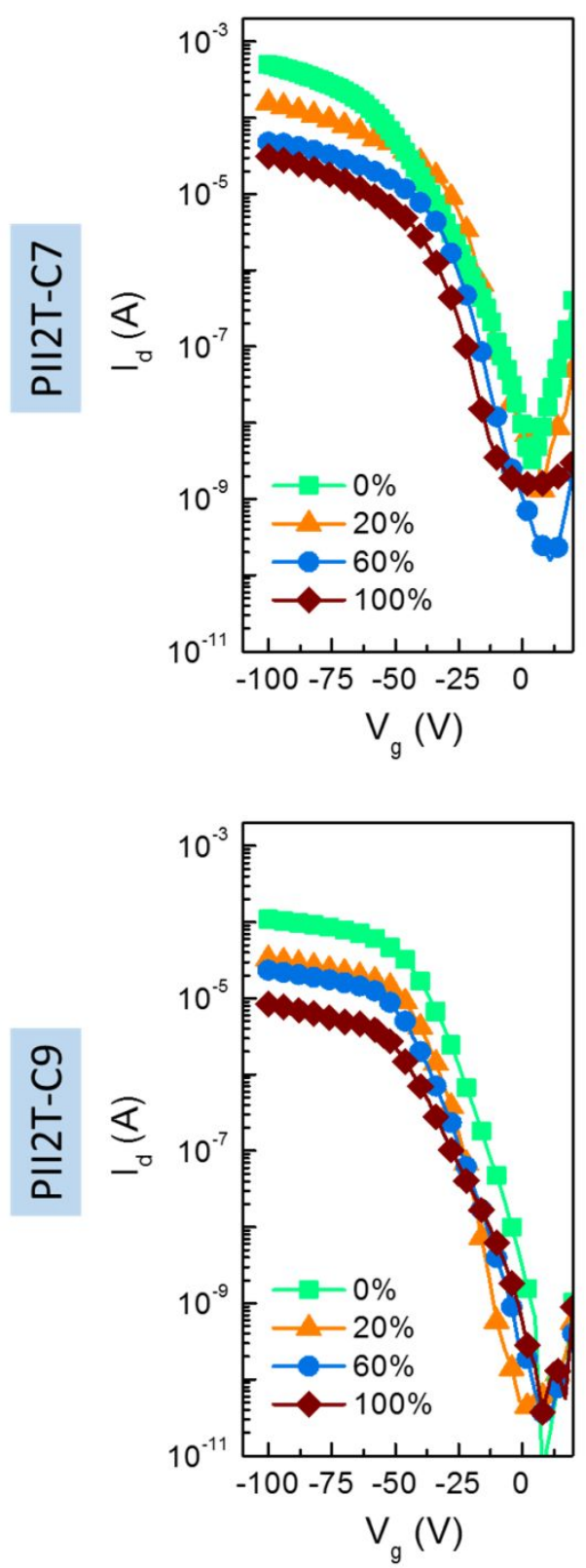

S D
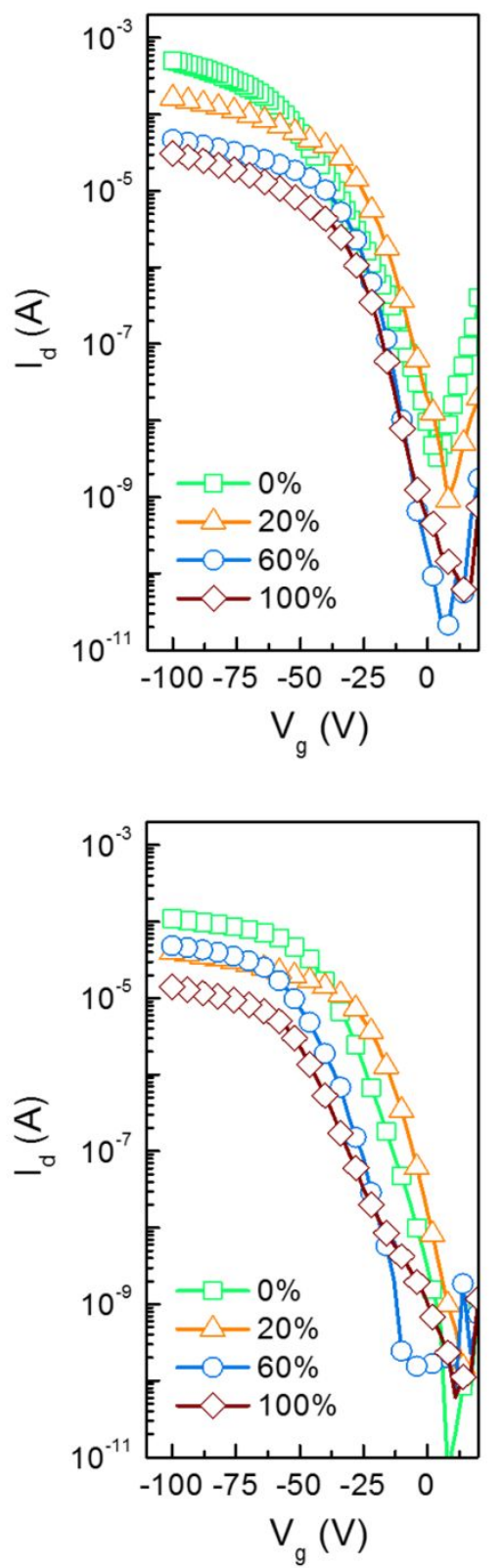

Figure S16. Transfer characteristics of FETs based on stretched PII2T-C7 and PII2T-C9 thin films.

Charge transport in both parallel and perpenduicular directions with respect to stretching direction are summarized. 

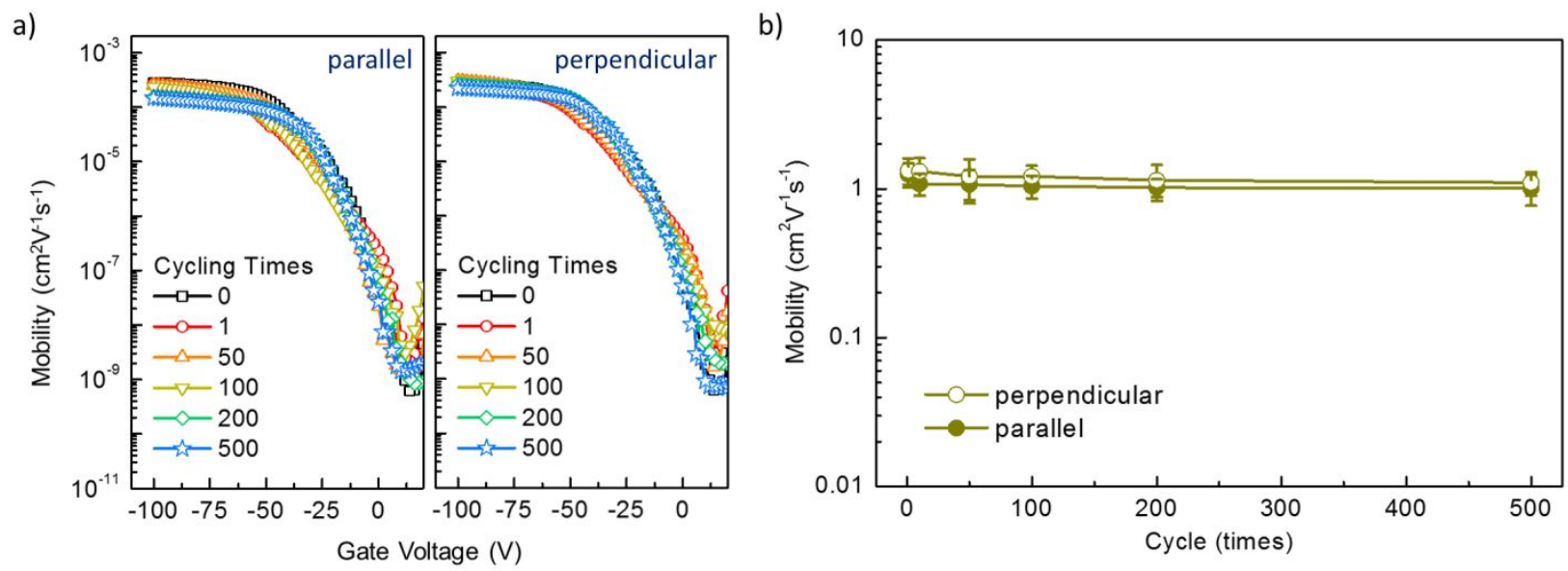

Figure S17. FET stability of PII2T-C10 film under 500 stretching/releasing cycles. (a) Transfer characteristics of PII2T-C10-based FETs under cycling test. Both parallel and perpendicular directions were analyzed. (b) Averaged mobility of PII2T-C10 films that were measured at 1, 10, 50, 100, 200 and 500 cycles. The mobility was averaged from at least 5 devices in 2 different batches. 
Table S1. State-of-art FET charge carrier mobility (i.e. mobility larger than $0.1 \mathrm{~cm}^{2} \mathrm{~V}^{-1} \mathrm{~s}^{-1}$ ) based on single semiconducting polymer thin film under strain

\begin{tabular}{|c|c|c|}
\hline Reference & Polymer & Mobility under strain \\
\hline 1. Wen et al., Macromolecules 2017, 50, 4982 & PII2T-PBA10 & $\begin{array}{l}0.1 \mathrm{~cm}^{2} \mathrm{~V}^{-1} \mathrm{~s}^{-1} \\
(\text { @ } 20 \% \text { strain })\end{array}$ \\
\hline 2. Mun et al., Adv. Funct. Mater. 2018, 28, 1804222 & C12-DPP & $\begin{array}{l}\sim 0.3 \mathrm{~cm}^{2} \mathrm{~V}^{-1} \mathrm{~s}^{-1} \\
(@ 50 \% \text { strain })\end{array}$ \\
\hline 3. Wang et al., Adv. Funct. Mater. 2016, 26, 7254 & 20DPPTTECX & $\begin{array}{l}\sim 0.1 \mathrm{~cm}^{2} \mathrm{~V}^{-1} \mathrm{~s}^{-1} \\
(@ 100 \% \text { strain })\end{array}$ \\
\hline 4. Lu et al., Adv. Electron. Mater. 2017, 3, 1600311 & P3 & $\begin{array}{l}0.1 \mathrm{~cm}^{2} \mathrm{~V}^{-1} \mathrm{~s}^{-1} \\
(@ 100 \% \text { strain })\end{array}$ \\
\hline $\begin{array}{l}\text { 5. Wang et al., Chem. Mater. 2019, DOI: } \\
\text { 10.1021/acs.chemmater. } 8 \text { b04314 }\end{array}$ & 5-Linear & $\begin{array}{l}0.3 \mathrm{~cm}^{2} \mathrm{~V}^{-1} \mathrm{~s}^{-1} \\
(@ 100 \% \text { strain })\end{array}$ \\
\hline \multirow[t]{2}{*}{ 6. Oh et al., Nature. 2016, 539, 411} & P3 & $\begin{array}{c}1 \mathrm{~cm}^{2} \mathrm{~V}^{-1} \mathrm{~s}^{-1} \\
\left.\text { (@100\% strain: perp. }{ }^{1}\right)\end{array}$ \\
\hline & P3 & $\begin{array}{c}0.1 \mathrm{~cm}^{2} \mathrm{~V}^{-1} \mathrm{~s}^{-1} \\
\left(@ 100 \% \text { strain: para. }{ }^{1}\right)\end{array}$ \\
\hline \multirow[t]{2}{*}{ 7. Wu et al., Macromolecules 2016, 49, 8540} & PII2T-C8 & $\begin{array}{c}1.05 \mathrm{~cm}^{2} \mathrm{~V}^{-1} \mathrm{~s}^{-1} \\
\left(@ 60 \% \text { strain: perp. }{ }^{1}\right)\end{array}$ \\
\hline & PII2T-C8 & $\begin{array}{c}0.93 \mathrm{~cm}^{2} \mathrm{~V}^{-1} \mathrm{~s}^{-1} \\
\left(@ 60 \% \text { strain: para. }{ }^{1}\right)\end{array}$ \\
\hline \multirow[t]{2}{*}{ This work } & PII2T-C10 & $\begin{array}{c}0.94 \mathrm{~cm}^{2} \mathrm{~V}^{-1} \mathrm{~s}^{-1} \\
\left(@ 100 \% \text { strain: perp. }{ }^{1}\right)\end{array}$ \\
\hline & PII2T-C10 & $\begin{array}{c}1.05 \mathrm{~cm}^{2} \mathrm{~V}^{-1} \mathrm{~s}^{-1} \\
\left.\text { (@) } 100 \% \text { strain: para. }{ }^{1}\right)\end{array}$ \\
\hline
\end{tabular}

${ }^{1}$ perp: charge transport direction perpendicular to the strain direction; para: charge transport direction parallel to the strain direction. 


\section{Reference}

S1. Mei, J.; Graham, K. R.; Stalder, R.; Reynolds, J. R. Org. Lett. 2010, 12, 660.

S2. Choi, Y. S.; Jo, W. H. Org. Electron. 2013, 14, 1621.

S3. Wu, H.-C.; Hung, C.-C.; Hong, C.-W.; Sun, H.-S.; Wang, J.-T.; Yamashita, G.; Higashihara,

T.; Chen, W.-C. Macromolecules 2016, 49, 8540.

S4. Hung, C.-C.; Nakahira, S.; Chiu, Y.-C.; Isono, T.; Wu, H.-C.; Watanabe, K.; Chiang, Y.-C.;

Takashima, S.; Borsali, R.; Tung, S.-H.; Satoh, T.; Chen, W.-C. Macromolecules 2018, 51, 4966. 